Tourism Ecological Footprint: Energy Consumption of Domestic and

\author{
International Tourists in Egypt \\ Hebat Allah Ali Sayed Gaafar \\ Faculty of Tourism and Hotels - Sadat City University
}

\begin{abstract}
Tourism Ecological Footprint (TEF) has been applied to monitor the environmental impact of the behavior and activities of tourists, in order to assess the sustainability of the tourism industry. This study aims to explore the attitudes as well as the behaviors of both domestic and international tourists towards energy consumption in the Egyptian destination. The study investigated the factors, which might affect the tourists' attitudes and behaviors towards energy consumption. The sample consisted of four hundred and fifty nine tourists (247 domestic tourists and 212 international tourists). Questionnaires were distributed in five tourism destinations in Egypt; Sharm El Shaikh, Hurghada, North Coast, Luxor and Aswan. The results identified significant differences between domestic and international tourists concerning their attitudes towards energy consumption, as international tourists' attitudes were more positive than those of domestic tourists. On the other hand, the domestic tourists' energy consumption behaviors were more positive than those of international tourists. The results showed that there was deficiency in energy saving campaigns in the Egyptian destination. From the managerial perspective, this paper provides tourists' energy-consumption patterns which may help policy makers to establish some guidelines in order to promote more environmentally-friendly forms of energy use behavior among tourists.
\end{abstract}

Keywords: Tourism Ecological Footprint, energy, consumption behavior, attitudes

\title{
Introduction
}

Tourism Ecological Footprint (TEF) has been developed by Wackernagel and Rees in 1996 to monitor and manage the global environmental impacts of the tourism industry, as to minimize the rate of greenhouse gases (GHGs) emissions resulting from tourism industry; it is now a major global environmental issue which faces all governments (Gössling et al., 2002; Kuo and Chen, 2009). The Ecological Footprint (EF) facilitates the tourism sector by amplifying essential knowledge about the environmental impact of tourism operation. In this respect, EF provides a profound managerial tool for achieving sustainable tourism. Whereas, the tourism industry has a significant negative impact on the global environment through emitting large quantities of greenhouse gases, the major cause of which is energy-use (Becken et al., 2003; Becken and Patterson, 2006; 


\section{Tourism Ecological Footprint: Energy Consumption of Domestic and International Tourists in Egypt}

Dolnicar et al., 2010). Those components of the tourism industry (e.g. accommodation, transport, attractions and activities) consume huge amounts of energy, especially from fossil fuels (Dwyer et al., 2010), and contribute to about $5 \%$ of total global $\mathrm{CO}_{2}$ emissions and14 \% of total global GHG emissions from human activities (World Tourism Organization et al., 2008).

Tourists have different consumption behaviors and activities and so the ecological consumption varies greatly as a result. EF can help a destination to direct its tourism policies towards increasing sustainability and prioritizing its efforts to reduce both domestic and international tourists' environmental impacts (Becken and Patterson, 2006; Peters and Schouten, 2006).

The aims of this paper are to:

- Provide an overview of the EF concept.

- Investigate the attitudes of both domestic and international tourists towards energy usage.

- Identify the differences of energy consumption behaviors between domestic and international tourists in Egypt.

- Investigate the factors that may influence tourists' energy consumption behaviors (Age, gender, educational background, and membership in environmental organizations) by using primary data.

The quantitative approach was applied to conduct this research. In accordance with this, questionnaires were distributed in five tourism destinations in Egypt. Understanding tourists' attitudes towards environment and energy consumption behaviors may potentially help the policy makers to promote more environmentally-friendly forms of energy-use behavior among tourists, an attempt to conserve the natural environment and support sustainability.

\section{Research Hypotheses}

According to the research aims, six hypotheses were derived:

H1: There are significant differences between domestic and international tourists' attitudes towards environment and energy usage.

H2: There is a significant difference between domestic and international tourists regarding their level of concern about energy use.

H3: There is a significant difference between domestic and international tourists regarding their level of commitment to act on energy saving.

H4: There is an association between the level of concern and commitment toward environment and energy issues

H5: There are significant differences between respondents' energy consumption behavior.

H6: Age, gender, educational background, and membership in environmental organizations have a significant impact on the energy-consumption behavior. 


\section{Literature Review}

\section{EF Concept}

The EF concept has gained widespread appeal and provides an innovative approach to communicating messages about the global impact of current resource consumption (Hunter, 2002). The EF provides a measure of demands upon the biological productivity and capacity of nature imposed by human lifestyles (Chen et al., 2007). The World Wild Life Fund (2012) has demonstrated that the average footprint of every citizen of the planet is greater than 1.8 global hectares (gha), and then the earth's resources are over-exploited and thus endangering the ability of future generations to lead a decent quality of life. Moreover, most over-consumption of natural resources occurred in developed countries, as the largest rate of EF is being in the United Arab Emirates (9.9gha) closely followed by USA (9.5 gha) (Pongsakornrungsilp, 2011).

The researchers have found the EF concept to be useful when examining the environmental impact from a particular type of activity such as tourism (Gössling et al., 2002; Patterson et al., 2007). In the tourism industry, EF has been applied to monitor the environmental impact of the behavior and activities of tourists, in order to assess the sustainability of the tourism industry (Kuo and Chen, 2009; Patterson et al., 2008; Sonak, 2004; Stoeglehner and Narodoslawsky, 2009). Indeed, Wackernagel and Yount (2000) mentioned that the international tourism is likely to occupy over $10 \%$ of the planetary ecological footprint.

Numerous previous studies have discussed the energy consumption of tourism taking into account the transportation, accommodation, and activities of tourists (Becken et al., 2003; Gössling and Hall, 2005). Tourist transportation is a major contributor to environmental pollution related to the transportation mode and distances traveled during a journey, the consumption of fossil fuels and generation of $\mathrm{CO}_{2}$ emissions. In hotels, air conditioning and lighting mean direct and indirect energy consumption (Wang, 2012; Wang and Huang, 2013). Several studies have demonstrated that hotels are among the highest energy consumption building types. Also, the consumption of electricity and fossil fuels are affected by the various activities carried out at the tourist sites, such as boat trips, jet skiing, and city tours, as well as visiting museums and eating in restaurants (Rahman et al., 2012; Taylor et al., 2010; Teng et al., 2012, Tsai et al., 2014).

\section{EF Definition}

Costanza (2000: 341) defined EF as an "area of productive land and water ecosystems required to produce the resources that the population consumes and assimilate the wastes that the population produces, wherever on Earth that land and water may be located". However, Wackernagel et al. (2005: 5) mentioned that "ecological footprint accounts document how much of the 


\section{Tourism Ecological Footprint: Energy Consumption of Domestic and International Tourists in Egypt}

annual regenerative capacity of the biosphere is required to renew the resource input of a defined population in a given year". Ross (2006: 5) stated that "The footprint expresses the area of land and sea that is required to feed us, provide resources, produce energy, assimilate waste, and to re-absorb the greenhouse gases produced by our use of fossil fuels. This approach uses land as its 'currency', and provides a notional figure - the global hectare (an area equivalent to a normal hectare but adjusted for average global productivity) - to quantify the area required to support an individual, a community or a nation's population at its present standard of living".

According to Venetoulis and Talberth (2008: 443) EF is " a measure of how much productive land and water an individual, a city, a country, or humanity requires to produce the resources it consumes and to absorb the waste it generates, using prevailing technology', Van den Bergh and Verbruggen (1999) mentioned that the EF is intended to provide an overview of the use of resources that can be attributed to final consumption. It accounts for the flows of energy and matter to and from a specific economy or activity, converted into corresponding land and water area needed to support these flows.

$\mathrm{EF}$ is an efficient tool for monitoring the contribution made by the tourism industry to the global warming. One of the major benefits of EF is enabling comparisons to be made between environmental impact and different sources of consumption on local and more global scales. As a consequence, it offers indicators to assess sustainable tourism development at local and global levels (Peng and Guihua, 2007). The EF may help policymakers to explore and compare the effects of a diverse range of factors at different destinations; EF facilitates more pro-active decision making as part of the process of sustainable planning. EF provides decision makers with information on ecological impacts rather than asking them to make judgments. Moreover, the footprint assesses the impact of tourism activities, and also provides an agenda for reducing footprint of tourists (Collins and Flynn, 2008; Peters and Schouten, 2006).

There are some limitations; especially, the overall EF of the tourism sector cannot always be precisely distinguished, due to its close links with other sectors. As Hunter (2002) has pointed out, the tourism industry is highly diverse because it comprises many trades and businesses, including the transport, accommodation, and food service industries, tour operators and various other kinds of private business. Additionally, the lack of an adequate method for accounting the main sources of consumption within tourism, such as waste contribution and energy-consumption, raises serious issues for sustainability monitoring.

Despite the EF's limitations, many scholars support the benefits of adopting the EF as an indicator capable of providing a global perspective on tourism's environmental impact (Barrett et al 2004; Becken et al., 2003; Huant and Shawn, 2007). Also, a growing number of regional and local tourism authorities have shown a strong interest in applying EF in order to measure the impact of tourists' activities on energy consumption. For example, South West Tourism (SWT) with the cooperation of the Stockholm 
Environment Institute (SEI), have employed the $\mathrm{EF}$ to manage the environment and the impact of tourism on it (Paul et al., 2010). Therefore, this research focused on the EF of both international and domestic tourists through investigating their energy consumption, which may help the Egyptian destination to develop tourism policies towards increasing sustainability and reducing the negative environmental impact of tourists.

\section{Understanding Tourist Behavior}

The potential threats posed by uncontrolled tourism to various destinations around the world, especially due to the demands of tourists, have been widely recognized since the development of the tourism industry (Dodds et al., 2010; Jackson et al., 1996). In recent years, the tourism sector has been considered as a significant contribute of to the negative environmental impact (Becken and Hay, 2007; Gössling and Hall, 2005). Therefore, studies of the impact of tourists' behaviors and patterns of consumption, especially of limited resources like energy, and also the negative impacts of tourism on the environment are becoming increasingly important. The tourism sector is highly considering, as well as responding to the widespread concerns about the future of the global environment. Also, the tourists' decisions concerning what kinds of transport, accommodation, and activities they choose to undertake, affect energy consumption and environmental degradation. So, tourists should take responsibility for the environmental impact of the tourism services they use, as their behavior and attitudes affect the environment sustainability (Becken et al., 2003; Becken, 2007; Dodds et al., 2010; Hudson and Ritchie, 2001; Kelly and Williams, 2007; Woodside and King, 2001).

Governmental organizations and the private sector need to work together to understand the behaviors of tourists for the purposes of developing effective and efficient plans for achieving their goals and reducing the negative effects of tourism. In order to achieve the latter, it is necessary to analyze both the tourists' behaviors (Becken and Hay, 2007; Swarbrooke and Horner, 2004), and the factors which influence their behavior (e.g. cultural backgrounds, attitudes, perceptions, motivations, income levels, etc...) (Kontogeorgopoulos, 2003). These data on tourists' backgrounds, attitudes, and behaviors may potentially help tourism policy makers develop guidelines to diminish the tourists' impact on the environment and generally make tourism more sustainable (Becken et al., 2003; Cao and Mokhtarian, 2005; Van Middelkoop et al., 2003).

\section{Methodology}

To investigate the attitudes toward environment as well as energy-consuming behaviors of both domestic and international tourists on vacation, questionnaires were developed in both English and Arabic languages. The 


\section{Tourism Ecological Footprint: Energy Consumption of Domestic and International Tourists in Egypt}

final stage of designing the questionnaires for this study was a pretest, which had already been undertaken in a pilot study. The questionnaire was pretested in order to give feedback on the wording, difficulty, and the time needed to fill in. The pilot survey was conducted in February 2014 in Hurghada. According to Ministry of Tourism (2014) Hurghada is considered one of the most preferable holiday destinations for both domestic and international tourists.

The final stage of designing the questionnaires for this research was a pretest which had already been undertaken in a pilot study. Before finalizing the questionnaire, a total of 60 surveys were randomly handed out to both domestic and international tourists. The results were analyzed to ensure the questions asked were relevant to the different types of tourists and can be understood across the different nationalities. The most significant issue raised was the amount of time taken to complete the questionnaire. The test highlighted that the respondents did not understand well the questions about energy consumption behavior and needed assistance to provide answers. So those open-ended questions were changed to closed questions. In other words, these open-ended questions needed to be simplified so that respondents could answer them without any assistance from the researcher. Consequently, the questions were improved. The feedback from participants also suggested some improvements regarding the wording. The responses given to each question helped to highlight problems with the wording of the questionnaires. Accordingly, the questionnaires were edited before the final version distribution.

Stratified random sampling method was selected to draw out samples of international and domestic tourists who visited the studied areas. The selection of participants for this research was based on "their proximity to the researcher and the ease with which the researcher can access them" (Jennings, 2001: 139). The respondents were informed about the purpose of this study, before they answered the questionnaires. They were also informed of their right to deny or withdraw their cooperation at any time. The researcher approached the respondents in a friendly manner. The data was gathered from tourists in a confidential manner.

This research employed both parametric and non-parametric statistics. For non-parametric statistics, the chi-square and Mann-Whitney tests, the most common nonparametric test of significance, were used to investigate the association of nominal or ordinal variables (Wang, 2011), to identify the differences and relationships between the types and volumes of energy-use by respondents. Additionally, $\mathrm{t}$ - independent test was used to investigate differences in energy-consuming behavior in relation to gender and tourism activities. 
The questionnaire consisted of four sections. The first section concerned with the personal background; age, gender, marital status, working

status, education, membership in environmental organization and country of origin. The second section focused on travel behavior characteristics; length of stay, type of tour, transport choices, main purposes of the visit and type of accommodation. The third section emphasized on the attitudes towards energy consumption which aimed to figure out attitudes towards environmental issues via a series of questions. The respondents were asked to rate the level of their concern about the environmental impact of their holiday and the level of their commitment to saving energy. This section discovered attitudes by using the 5 Likert scale. The respondents were asked to rate their level of concern using the following response categories: 'Not concerned at all' (1), 'Not concerned' (2), 'Uncertain' (3), 'Concerned' (4), and 'Extremely concerned' (5); and they were asked to rate their level of commitment using the response categories: 'Not committed at all' (1), 'Not committed)' (2), 'Uncertain'(3), 'Committed' (4) and 'Totally committed' (5).

The fourth section investigated the energy consumption behavior, whereas the respondents were asked about patterns of their energy consumption in accommodation, in addition to their activities by using the following response categories 'Never' (1), 'Rarely' (2), 'Sometimes' (3), 'Usually' (4), and 'Always' (5). Also, respondents were asked about the energy saving campaigns in Egypt through using the following response categories 'Not well at all' (1), 'Not very well' (2), 'Quite well' (3), 'Very well' (4), and 'Extremely well' (5). Statistical Package for the Social Sciences (SPSS) version (16) was used to analyze the research findings.

The survey covered the main tourism destinations in Egypt: Sharm El Shaikh, Hurghada, North Coast, Luxor and Aswan .These sites were chosen to reflect the diversity of the tourists in Egypt: that is, in terms of their nationality, age, activities, and so on. Following the quantitative research approach, 650 questionnaires were distributed in the following accommodation type (5 Star hotel; 300 questionnaires, 4 Star hotel; 200 questionnaires, and 3 Star hotel; 150 questionnaires), where tourists could leave the survey with the reception staff at the desk. The researcher checked that the returned questionnaires were answered properly and completed; five hundred questionnaires were received but only 459 of them were suitable for statistical analysis.

\section{Reliability and Validity}

Researchers must be concerned with reliability and validity in order to ensure the quality and credibility of the research findings. Reliability can be defined as "the stability and consistency of the results derived from research." (Chisnall, 2001, 114). In other words, reliable research should provide findings which support each other. If the coefficient alpha is $>0.70$ 


\section{Tourism Ecological Footprint: Energy Consumption of Domestic and International Tourists in Egypt}

there is a strong suggestion of strong item covariance. Therefore, this result indicates strong item covariance. The Cronbach's Alpha value was 0.898

(based on a standardized item). Accordingly, the results considered sufficiently supportive of consistency and the questionnaires were distributed to the respondents. Meanwhile, validity is a quality control process that guarantees that research projects achieve whatever goals they claim to. Two types of validity have been identified in the research: internal validity, and external validity (Yin, 2003). Internal validity is highlighted in the causal research because it is concerned with the actual relationship between two variables (i.e. the dependent and independent variables). More specifically, internal validity ensures that changes to dependent variables are caused by changes to independent variables, whereas, external validity refers to the general capability of research findings (Ruane, 2005).

\section{Results}

\section{The Demographic Characteristics of Respondents}

Table (1) shows that the gender distribution of the respondents was: $57.3 \%$ male and $42.7 \%$ female. The average age of tourists of the respondents is approximately 38 years old and the dominant age group is 31 to 40 years $(36.6 \%)$, followed by the age group of 21 to 30 years $(29.6 \%)$. The majority of respondents $(38.3 \%)$ are single, followed by the married group $(36.8 \%)$. The wide ranges of respondents' career have been grouped from the opened question in tourists' survey. The results show that nearly half of the respondents are employees of private companies (47.5\%) and a significant portion are business owners $(17.9 \%)$.

Regarding the educational backgrounds of the respondents, as $64.5 \%$ have university level education and $23.5 \%$ are postgraduates. Data also shows that the domestic tourists represented the largest share of the total number of respondents $(53.8 \%)$ followed by international tourists $(46.2 \%)$. Nevertheless, only $11.5 \%$ of respondents belong to environmental groups or organizations.

Table 1: Frequencies and Percentages of Respondents Classified by Demographic Characteristics

\begin{tabular}{lcc}
\hline Tourists characteristics & Frequency $(\mathbf{n = 4 5 9})$ & \% \\
\hline Gender & 263 & 57.3 \\
Male & 196 & 42.7 \\
Female & & \\
Age $($ Mean=37.5 years) & 33 & 7.2 \\
Less than 21 years old & 136 & 29.6 \\
1 - 30 years old & 168 & 36.6 \\
- 40 years old & 100 & 21.8 \\
41 - 50 years old & 22 & 4.8 \\
More than 51 years old & & 38.3 \\
Marital Status & 176 & \\
Single & &
\end{tabular}




\section{Hebat Allah Ali Sayed Gaafar}

\begin{tabular}{lrc}
\hline Married & 169 & 36.8 \\
Divorced & 73 & 15.9 \\
Widow & 41 & 8.9 \\
Occupation & & \\
Business Owner & 218 & 17.9 \\
Private company employee & 66 & 47.5 \\
Government officer & 28 & 14.4 \\
Student & 34 & 6 \\
Engineer and technician & 5 & 74.1 \\
Others - physicians, retirements, etc. & & 1.1 \\
Education Level & 55 & 12 \\
Up to high school & 296 & 64.5 \\
Bachelor & 108 & 23.5 \\
Postgraduate & & \\
Place of Origin & 247 & 53.8 \\
Egypt & 64 & 13.9 \\
England & 30 & 6.5 \\
Switzerland & 15 & 3.3 \\
Germany & 63 & 13.8 \\
Russia & 40 & 8.7 \\
Italy & & \\
Environmental Group membership & 53 & 11.5 \\
Yes & 406 & 88.5 \\
No & & \\
\hline
\end{tabular}

\section{Respondents' Travel Characteristics}

The data represented in table (2) illustrates that (41.8\%) of respondents preferred package tour services in which all transport, tour operation and accommodation are included or managed, while $(31.6 \%)$ of them travelled in a semi package-holiday. Most respondents (66.4\%) stayed at the destination from 4 to 6 nights, while $30.1 \%$ stayed from 1 to 3 nights. The majority of respondents travelled to the destination with friends, followed by travelled with family $(46.6 \%, 31.6 \%)$. Concerning the purpose of visiting, $91.1 \%$ of all respondents travelled on holiday. Concerning choices of transport table (2) shows that air travel is currently the most popular mode of transport as $37.9 \%$ of respondents travelled to the destination by plane. The largest portion of respondents stayed in luxury hotels $(27.2 \%)$, followed by 4 star and 3 star hotels $(19.6 \%, 17.6 \%)$.

Table 2: Frequencies and Percentages of Respondents' Travel Characteristics

\begin{tabular}{lcc}
\hline Travel characteristics & Frequency & Percent \\
\hline Travel Arrangement $(\boldsymbol{n = 4 5 9 )}$ & 192 & 41.8 \\
Packaged tour & 145 & 31.6 \\
Semi-package tour & 122 & 26.6 \\
Independently & & \\
Length of Stay: & 138 & 30.1 \\
1 - 3 nights & 305 & 66.4 \\
4 - 6 nights & 16 & 3.5 \\
7 - 9 nights & & 8.1 \\
Travel & 37 & \\
Alone & & \\
\hline
\end{tabular}




\section{Tourism Ecological Footprint: Energy Consumption of Domestic and International Tourists in Egypt}

\begin{tabular}{lrr}
\hline As a couple & 63 & 13.7 \\
With friends & 214 & 46.6 \\
With family & 145 & 31.6 \\
The purpose of visiting & & \\
On holiday & 418 & 91.1 \\
Visiting friends or relatives & 41 & 8.9 \\
Mode of transport for travel to destination & & \\
By plane & 174 & 37.9 \\
By bus & 150 & 32.7 \\
Private Car & 98 & 21.3 \\
Train & 37 & 8.1 \\
Accommodation & & \\
$5^{*}$ hotel & 125 & 27.2 \\
$4^{*}$ hotel & 90 & 19.6 \\
$3^{*}$ hotel & 81 & 17.6 \\
Resort & 98 & 21.4 \\
Staying at friends & 65 & 14.2 \\
\hline
\end{tabular}

\section{Tourists' Attitudes Towards The Energy Usage}

Using Likert scales, the respondents were asked to rate their attitudes towards conserving environment at the destination and where they believe responsibility falls among stakeholders in the tourism industry to tackle environmental problems. Mann- Whitney test was conducted to investigate whether there are differences between domestic and international tourists concerning their attitudes towards the environment and energy usage.

\section{Table 3: Differences Between Respondents' Attitudes Towards} Environment and Energy Usage

\begin{tabular}{|c|c|c|c|c|}
\hline Attitude about energy-use & $\begin{array}{l}\text { Domestic } \\
\text { tourists } \\
\text { Mean } \\
\text { Rank }\end{array}$ & $\begin{array}{l}\text { International } \\
\text { tourists } \\
\text { Mean Rank }\end{array}$ & $\mathbf{Z}$ & Sig. \\
\hline $\begin{array}{l}\text { Reducing environmental impacts is important } \\
\text { to preserve environment at the destination }\end{array}$ & 167.97 & 324.41 & -13.580 & 0.000 \\
\hline $\begin{array}{l}\text { It's not the tourists' responsibility to pay attention } \\
\text { to energy usage during their trip }\end{array}$ & 215.54 & 252.01 & -3.075 & 0.002 \\
\hline $\begin{array}{l}\text { Energy should be part of the environmentally } \\
\text { friendly practice of tourism business }\end{array}$ & 165.85 & 327.64 & -13.615 & 0.000 \\
\hline $\begin{array}{l}\text { I like to follow the guidelines and support } \\
\text { environmentally friendly programs at the destination }\end{array}$ & 173.84 & 315.48 & -11.717 & 0.000 \\
\hline $\begin{array}{l}\text { Honestly, the energy saving campaigns quite } \\
\text { bother me when I'm on holiday }\end{array}$ & 215.23 & 252.48 & -3.188 & 0.000 \\
\hline On holidays I don't have to think about energy usage & 208.71 & 262.41 & -4.656 & 0.000 \\
\hline
\end{tabular}

In table (3), it was found that there were significant differences $(p<0.05)$ favoring the international tourists as their mean ranks were greater than the mean ranks of the domestic tourists. Therefore, the first hypothesis was supported.

Mann- Whitney test was used to indicate whether there is a significant difference between domestic and international tourists in their level of 
concern about global environmental problem, especially in energy use. A significant difference was found between domestic and international respondents' level of concern $(z=6.452$, Sig. $=0.000)$. This significant

difference favors the international tourists as the mean rank was 276.80 while the domestic tourists' mean rank was 199.25. Accordingly, the second hypothesis was supported.

The respondents were also asked to rate their level of commitment to act on energy saving in the destination by using Likert scale. Mann- Whitney test was used to indicate whether there is a difference between domestic and international tourists concerning their level of commitment $(\mathrm{z}=3.972$; Sig. $=$ $0.000)$. This significant difference favors the international tourists as the mean rank was (258.49), while the domestic tourists achieved (211.28). Subsequently, the third hypothesis was supported. In order to explore if there is an association between respondents' level of concern about the environment and energy usage, and the extent to which they committed to modify their behavior to lessen their impact on the environment at the destination; these two variables was subject to the Chi-square test and categorized into three groups with reference to the respondents' answers, the results of which are shown in Table (4).

Table 4: Number and Percentage of Respondents and the Association Between the Level of Concerns and Commitment Toward Environment and Energy Issues

\begin{tabular}{|c|c|c|c|c|c|c|c|}
\hline \multirow{2}{*}{$\begin{array}{l}\text { Level of } \\
\text { commitment to act } \\
\text { On global } \\
\text { environmental } \\
\text { Problem and energy } \\
\text { saving }\end{array}$} & \multicolumn{6}{|c|}{ Level of concern toward environmental problem } & \multirow{2}{*}{$\begin{array}{l}\text { Total } \\
\text { N- (\%) }\end{array}$} \\
\hline & $N$ & $\%$ & $N$ & $\%$ & $N$ & $\%$ & \\
\hline Not Committed & 29 & 0.6 & 4 & 11.1 & $\overline{3}$ & & $36-($ \\
\hline Uncert & 29 & 7.9 & 82 & 23.3 & 231 & 69 & $342-(100)$ \\
\hline Committed to act & 19 & 23.5 & 4 & 4.9 & 58 & 71.6 & $81-(100)$ \\
\hline Total & & & & & & & $459-(100)$ \\
\hline
\end{tabular}

Note: Chi-square $=944.956$, Sig. $=0.001$

A significant association was found between the respondents' level of concern and the level of commitment (chi-square $=944.956$, Sig. $=0.001)$. Indeed, a higher proportion of respondents who expressed no concern about environmental problems also indicated that they were not committed to act on by saving energy $(n=29 ; 0.6 \%)$ : this compares to the portion who expressed concern about their environmental impact and also commitment to act on it by saving energy $(\mathrm{n}=58 ; 71.6 \%)$. Accordingly, the fourth hypothesis was supported.

\section{Tourists' Resource Consumption}

Tourists' energy Consumption in Accommodations 


\section{Tourism Ecological Footprint: Energy Consumption of Domestic and International Tourists in Egypt}

Regarding energy consumption patterns in using air condition in accommodation; The domestic tourists turn the air condition on for most of the time they stay in accommodation with 7.50 hours on average of staying,

whereas, international tourists turn the air conditioning on for most of the time they stay in accommodation with 9.70 hours on average of staying. Most domestic tourists $(74.8 \%)$ stayed in accommodation about $6-10$ hours, while almost a half of the international tourists (55\%) stayed in accommodation about 11 - 15 hours per day. By comparing air condition usage during daytime and nighttime, Domestic tourists used air condition in the daytime (4 hours per day on average) less than the nighttime (5 hours per night on average). On the other hand, the international tourists used air condition in the day time (6 hours and 28 minutes on average) less than the night time (7.48 hours per night on average). It is noteworthy that the most effective air condition temperature for saving energy and decreasing carbon footprint is $26{ }^{0} \mathrm{C}$, however only $5.45 \%$ of international tourists and $16.89 \%$ of domestic tourists stated this as the temperature set. Most of international tourists $89.9 \%$ stated $20{ }^{\circ} \mathrm{C}$ as against $70 \%$ of domestic tourists who stated 24 ${ }^{0} \mathrm{C}$ for air Condition.

Table 5 : Air Conditioned Use Behavior in Accommodation

\begin{tabular}{lcc}
\hline Behavior in accommodation & $\begin{array}{l}\text { Domestic } \\
\text { tourists } \\
(\mathbf{n = 2 4 7}) \\
(\mathbf{\%})\end{array}$ & $\begin{array}{c}\text { International } \\
\text { tourists } \\
(\mathbf{n = 2 1 2}) \\
(\mathbf{\%})\end{array}$ \\
\hline Total hours of staying in accommodation per day & & \\
$1-5$ hours/day & 23.2 & 14.5 \\
$6-10$ hours/day & 74.8 & 30.5 \\
$11-15$ hours & 2.0 & 55.0 \\
Hours of using air condition in day time & 20 & 12 \\
$1-3$ hours/day & 75 & 13 \\
$4-6$ hours/day & 5 & 75 \\
More than 6 hours & & \\
Hours of using air condition at night & 15 & 10 \\
$1-3$ hours/day & 70 & 12 \\
$4-6$ hours/day & 15 & 78 \\
More than 6 hours & & \\
The set-point temperature of air-conditioned room & 0.00 & 2.00 \\
Less than 20 Co & 5.00 & 89.90 \\
$20{ }^{\circ} \mathrm{C}$ & 4.11 & 1.60 \\
$21{ }^{\circ} \mathrm{C}$ & 3.00 & 1.05 \\
$22{ }^{\circ} \mathrm{C}$ & 1.00 & 0.00 \\
$23{ }^{\circ} \mathrm{C}$ & 70.00 & 0.00 \\
$24{ }^{\circ} \mathrm{C}$ & 0.00 & 0.00 \\
$25{ }^{\circ} \mathrm{C}$ & 16.89 & 5.45 \\
More than $25{ }^{\circ} \mathrm{C}$ & & \\
\hline
\end{tabular}

Tourists' Water Consumption in Accommodations

Concerning the respondents' water consumption patterns in accommodation in terms of their showering behavior, a large portion of domestic respondents $(60.3 \%)$ took a shower twice a day, while the rest 
showered once per day. These findings also show that $(30.7 \%)$ of international respondents showered once per day and $(69.3 \%)$ showered

twice per day. Accordingly, the water consumption of international tourists is more than the domestic tourists.

\section{Energy Consumption in Transport}

Table (6) shows that a considerable proportion of domestic respondents (40.9\%) used Taxi followed by private transportation (30.8\%), while using train was of the lowest percent $(7.3 \%)$. On the other hand, most of international respondents $(60.3 \%)$ rely on bus as their main mode of transport followed by Taxi (30.3\%).

Table 6: Frequencies of Respondents' Transport at The Destination

\begin{tabular}{lcccc}
\hline Mode of transport & $\begin{array}{c}\text { Domestic tourists } \\
(\mathbf{n = 2 4 7}) \\
\text { Frequency }\end{array}$ & $\mathbf{\%}$ & Frequency & \% \\
\hline Bus & 52 & 21 & 128 & 60.3 \\
Private & 76 & 30.8 & 0 & 0 \\
Taxi & 101 & 40.9 & 64 & 30.3 \\
Train & 18 & 7.3 & 20 & 9.4 \\
\hline
\end{tabular}

\section{Energy Consumption Behavior}

Mann Whitney $U$ test illustrated significant differences between the two studied groups concerning their energy consumption behavior. There were five attributes displayed to measure energy consumption behaviors; "Keep the heating (or the air conditioner) on for most of the day" ( $\mathrm{z}=-4.119$, $\mathrm{P}=0.000)$, "Turn off the light, when I go out" $(\mathrm{z}=-8.913, \mathrm{p}=0.000)$, "Need to wash your bath towel after each day's use" $(\mathrm{z}=-.199, \mathrm{p}=0.042)$, "Save energy such as electricity, as much as I can" $(\mathrm{z}=-13.249, \mathrm{p}=0.000)$, "Willing to pay more for environmentally friendly product" $(\mathrm{z}=-6.448, \mathrm{p}=0.000)$. These differences are in favor of the international respondents in the first and the last items as their mean ranks are higher than those of the domestic respondents, but the other consumption behavior differences are in favor of the domestic respondents as shown in table 7. Accordingly, the fifth hypothesis was supported.

\section{Table 7: Differences Between Respondents' Energy Consumption} Behavior

\begin{tabular}{llcccc}
\hline Consumption behavior & $\begin{array}{l}\text { Domestic } \\
\text { tourists } \\
\text { Mean Rank }\end{array}$ & $\begin{array}{l}\text { Internation } \\
\text { al tourists } \\
\text { Mean } \\
\text { Rank }\end{array}$ & $\mathbf{z}$ & Sig. \\
\hline $\begin{array}{l}\text { Keep the heating (or the air conditioner) } \\
\text { on For most of the day. }\end{array}$ & 209.66 & 258.22 & -4.119 & .000 \\
$\begin{array}{l}\text { Turn off the light, when I go out } \\
\begin{array}{l}\text { Need to wash your bath towel after each } \\
\text { day's use }\end{array}\end{array}$ & 271.52 & 164.75 & -8.913 & .000 \\
& 229.94 & 189.58 & -.199 & .022 \\
\end{tabular}




\section{Tourism Ecological Footprint: Energy Consumption of Domestic and International Tourists in Egypt}

\begin{tabular}{lllll}
\hline $\begin{array}{l}\text { Save energy such as electricity, as much } \\
\text { as I can }\end{array}$ & 292.39 & 133.21 & -13.249 & .000 \\
$\begin{array}{l}\text { Willing to pay more for environmentally } \\
\text { friendly product }\end{array}$ & 199.28 & 273.91 & -6.448 & .000 \\
\hline
\end{tabular}

In order to investigate the factors that influence the energy-use behavior of the respondents, t-distribution test, and Chi square $\left(X_{2}\right)$ tests were used to explore the association and mean differences between energy-use behavior and gender, tourists' backgrounds, age and membership of environmental organization.

Table 8: The t-test Results with the Mean Difference of Energy Consumption in Different Genders

\begin{tabular}{llllll}
\hline Gender & $\mathbf{N}$ & Mean & SD & $\begin{array}{c}\boldsymbol{t} \text { - } \\
\text { value }\end{array}$ & Sig. \\
\hline Male & 196 & 3.039 & 0.478 & & \\
Female & 263 & 2.952 & 0.477 & 1.950 & 0.004 \\
\hline
\end{tabular}

As seen from table 8 gender affects the energy consumption behavior, as male tourists tended to use energy more than female tourists $(t=1.950, \mathrm{p}=$ $0.004)$.

Table 9: Chi- Square Tests the Association Between Different Factors and Energy Consumption Behavior

\begin{tabular}{lcc}
\hline Factor & Chi- square & Sig. \\
\hline Educational Background & 309.244 & 0.003 \\
Membership of environmental organization & 33.614 & 0.001 \\
Age & 212.400 & 0.001 \\
\hline
\end{tabular}

The results, of Table 9, show a significant association between the qualification of respondents and their consumption behavior (Chi-square $=$ 309.244, Sig. < 0.05). Also there is a significant relation between the age of respondents and their consumption behavior (Chi-square $=212.400$, Sig. < $0.05)$. This means that the ages of the respondents significantly influence their consumption behavior, again there is a significant association between the membership of environmental organization and their consumption behavior (Chi-square $=33.614$, Sig. $<0.05$ ). Accordingly, the sixth hypothesis was supported.

Regarding respondents' opinion about energy saving campaigns in Egypt, the domestic respondents stated that they are not very well (mean $=$ 1.88), while the international respondents assured that campaigns in Egypt are not well at all $($ mean $=1.21)$.

Table 10: Frequencies and Percentage of Respondents Concerning Energy Saving Campaigns 


\section{Hebat Allah Ali Sayed Gaafar}

\begin{tabular}{lcccc}
\hline $\begin{array}{l}\text { Opinion about Energy } \\
\text { campaign In Egypt }\end{array}$ & \multicolumn{2}{c}{$\begin{array}{c}\text { Domestic tourists } \\
(\mathbf{n}=\mathbf{2 4 7})\end{array}$} & \multicolumn{2}{c}{$\begin{array}{c}\text { International tourists } \\
(\mathbf{n = 2 1 2})\end{array}$} \\
& \multicolumn{2}{c}{ Frequency } & \% & \multicolumn{2}{c}{ Frequency } & \% \\
\hline Not well at all & 219 & 88.7 & 147 & 69.3 \\
Not very well & 28 & 11.3 & 43 & 20.3 \\
Quite well & 0 & 0 & 22 & 10.4 \\
\hline
\end{tabular}

\section{Tourists' Activities On Holidays}

Most tourism related activities require energy directly in the form of fossil fuels or indirectly in the form of electricity often generated from petroleum, coal or gas. This consumption leads to the emission of greenhouse gases, mainly carbon dioxide (Sisman, 2007). $t$-independent test was applied to investigate whether there are significant differences between domestic and international tourists concerning tourism activities on their holidays.

Table 11: $t$-test Results of Mean Differences of Tourism Activities Between Domestic and International Tourists

\begin{tabular}{llllll}
\hline Activity & $\begin{array}{l}\text { Domestic } \\
\text { tourists Mean }\end{array}$ & $\begin{array}{l}\text { International } \\
\text { tourists Mean }\end{array}$ & S.D & $\begin{array}{c}t \text { - } \\
\text { value }\end{array}$ & Sig. \\
\hline Sightseeing & 2.49 & 3.56 & 0.62 & 17.200 & 0.019 \\
Swimming & 2.68 & 2.72 & 0.88 & 0.540 & 0.000 \\
Snorkeling & 1.00 & 1.58 & 0.69 & 15.710 & 0.000 \\
Shopping & 2.61 & 2.23 & 0.81 & 5.496 & 0.000 \\
Joining nightlife & 2.33 & 2.03 & 0.64 & 1.624 & 0.000 \\
Motorized water activities & 2.05 & 3.50 & 0.84 & 8.304 & 0.001 \\
\hline
\end{tabular}

As shown in Table 11, there are significant differences between domestic and international tourists concerning the duration of participated activities. These differences were in favor of the international tourists regarding the following activities; sightseeing, swimming, snorkeling, and motorized water activities. While the significant differences in shopping and joining nightlife were in favor of the domestic tourists.

Based on the preceding results, the following model is developed to illustrate the differences between domestic and international tourists concerning their attitudes towards environment and energy-use, level of concern towards environmental problem, energy consumption behavior, tourism activities and level of commitment to act on energy saving. 


\section{Tourism Ecological Footprint: Energy Consumption of Domestic and International Tourists in Egypt}

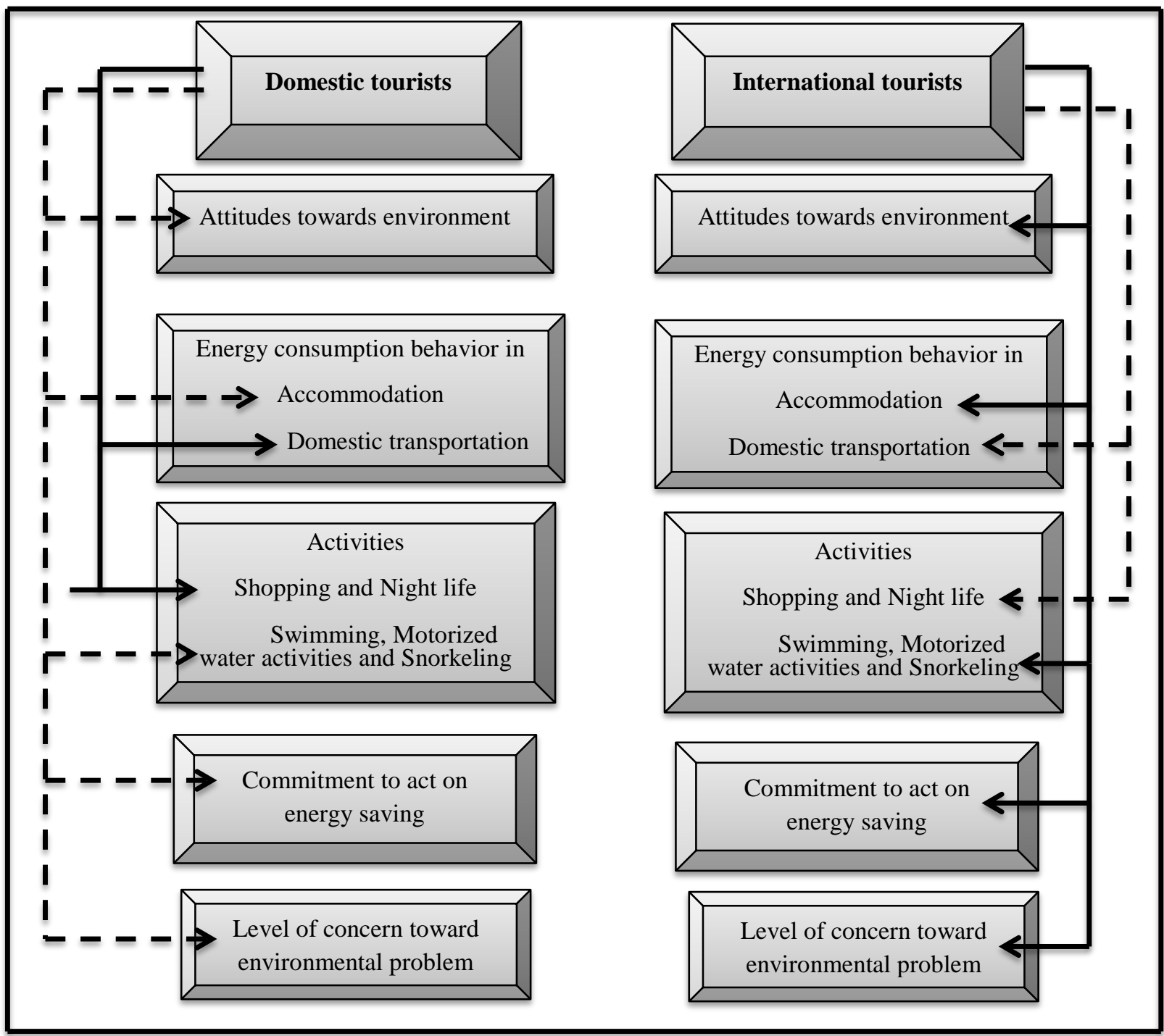

Figure 1: The Differences Between Domestic and International Tourists Concerning Their Attitudes and Energy Consumption behavior

Note: $\longrightarrow$ more influential power

$-\boldsymbol{C} \rightarrow$ Less influential power

The previous model is revealed for providing the different patterns of both international and domestic tourists' energy consumption that influence EF in Egypt. Therefore, a key contribution to knowledge made by this study is that it is the first attempt, in Egypt, to study the attitudes of 
international and domestic tourists towards the environment, their patterns of energy consumption, the factors that influence them, and the concept of EF. This research illustrates the energy consumption behavior of both domestic and international tourists, which will help tourism policy-makers to develop legislative programs to promote and enforce tourists to diminish energy consumption, including setting eco-friendly tourists' policies.

\section{Limitation of the Study and future research implications}

The researcher couldn't calculate the EF of both domestic and international tourists due to poor statistical database for quantifying the EF of tourism. This problem has been mentioned in many works (Cole and Sinclair, 2002; Patterson et al., 2008). In regard to this issue Gössling et al. (2002: 209) have stated: "EF calculation is often difficult to apply because it requires a detailed database on consumption and biomass yield figures. Such data is often difficult to obtain due to insufficient statistical databases, lack of transparency or unwillingness to cooperate particularly, the application of model in developing countries".

This study opens up a range of possibilities for future research on the environmental impact of tourism. It is important that future research involving the concept of EF gives consideration to the broader EF of tourism not just in terms of energy consumption but also of all the other kinds of resources used in tourism. Further studies should also be undertaken to improve our understanding of the negative effects of tourism on the environment, and so can find better ways of encouraging tourists to lessen

their environmental impact. It would be also worthwhile applying EF model on assessing the sustainability of tourism development.

\section{Conclusion}

This study explored the attitudes of domestic and international tourists towards environment and energy-use as well as their energy consumption behaviors. The results related to tourists' attitude towards environment reveal that there are significant differences between domestic and international respondents' attitudes towards reducing environmental impacts. These differences were in favor of international tourists, as their attitudes towards environment and energy use are more positive than the domestic tourists, as they tend to focus on their leisure activities, rather than commit to act eco-friendly behavior.

Concerning energy consumption in transport, it was found that international tourists consume energy more than domestic tourists as they use plane to reach the Egyptian destination, but most of the domestic tourists travel to their destination by private cars. With reference to Gössling et al. (2002) air travel emits higher levels of $\mathrm{CO}_{2}$ than other modes of transport. On the contrary, domestic tourists consume more energy than international tourists in the domestic transport, whereas most of international tourists rely on buses, but domestic tourists depend on taxis and private cars. So, the domestic tourists' transport emits greater levels of $\mathrm{CO}$. 


\section{Tourism Ecological Footprint: Energy Consumption of Domestic and International Tourists in Egypt}

In relation to energy consumption behavior in accommodation, the study revealed that the international tourists stay longer than domestic tourists; in addition, they turn on the air condition for most of time, so their energy consumption in the accommodation will be more than the domestic tourists. It was found that domestic tourists try to save energy in terms of electricity more than the international tourists and they are keen about turning off light when they go out, so the domestic tourists' energy consumption behavior in accommodation is better than the international tourists.

Regarding water consumption in the accommodation, the international tourists consume more water than the domestic tourists in terms of their showering behavior. The level of concern of international tourists about environmental impact of their holiday is better than the domestic tourists; also the international tourists' level of commitment to act on energy saving in the destination is more positive than the domestic tourists. It was found that there is a discrepancy between the level of environmental concern expressed by tourists and how far they are committed to acting on this concern, when they are on holiday. This research result implies that people tend to adopt less environment friendly patterns of behavior when they are on holiday.

Regarding the participated tourism activities on holidays, the tourists' decisions concerning what kinds of activities they choose to undertake, affect energy consumption and environmental degradation as international tourists spent more time than domestic tourists to practice the following tourism activities; sightseeing, swimming, snorkeling and motorized water activities. According to (Dietz et al., 2007) motorized water activities such as diving, jet

skiing, etc. consume more energy than sightseeing or any other activities. Accordingly, the international tourists consume more energy than domestic tourists in the tourism activities.

The study explored the factors that might influence energy-use behavior. In particular, age, gender and educational background of tourists and membership of environmental organizations have impacts on the respondents' behavior. With regard to gender; male tourists tended to use energy more than female ones. However, different age groups influence the respondents' energy-use behavior, highly-educated tourists and members in environmental organizations often behave in more environment friendly ways at the destinations.

The negative energy consumption behavior may result from less information about energy saving they receive at the destination as all respondents stated that energy saving campaigns are very bad in the Egyptian destination. Accordingly, policy makers must develop comprehensive campaigns to enhance the awareness of the tourists about their energy consumption, as their behavior and attitudes affect the environment sustainability.

The provided information about tourists' backgrounds, attitudes, and behaviors in this research, may help tourism policy makers develop guidelines, in order to reduce the tourists' negative impacts on the 
environment and generally make tourism more sustainable. As tourism policy makers can develop legislative programs to promote and enforce tourists to diminish energy consumption, including setting eco-friendly tourists' policies.

\section{References:}

- Barrett, J., Cherrett, N., and Birch, R. (2004) Exploring the Application of the Ecological Footprint to Sustainable Consumption Policy. Proceedings of the International Workshop on Driving Forces of and Barriers to Sustainable Consumption (pp 234 - 247). University of Leeds, UK.

- Becken, S. (2007). Tourists' Perception of International Air travel's Impact on the Global Climate and Potential Climate Change Policies. Journal of Sustainable Tourism, 15 (4), 351- 368 .

- Becken, S. \& Hay, J. (2007). Tourism and Climate Change - Risks and Opportunities, Channel View Publications, Cleveland.

- Becken, S. \& Patterson, M. (2006). Measuring National Carbon Dioxide Emissions from Tourism as a Key Step Towards Achieving Sustainable Tourism. Journal of Sustainable Tourism, 14 (4), 323 - 338.

- Becken, S., Simmons, D.G. \& Frampton, C. (2003). Energy Use Associated with Different Travel Choices. Tourism Management, 24, 267-277.

- Cao, X. \& Mokhtarian, P.L. (2005) .How Do Individuals Adapt Their Personal Travel? A Conceptual Exploration of the Consideration of Travel-Related Strategies. Transport Policy, 12, $199-206$.

- Chen, B., Chen, G.Q., Yang, Z.F., \& Jiang, M.M. (2007). Ecological Footprint Accounting for Energy and Resource in China, Energy Policy, 35, 1599 - 1609.

- Chisnall, P. (2001). Marketing Research, Ed.6. Berkshire: McGraw-Hill Publishing Company.

- Cole, V. and Sinclair, A.J. (2002). Measuring the Ecological Footprint of a Himalayan Tourist Center. Mountain Research and Development, 22 (2), 132-141.

- Collins, A. \& Flynn, A. (2008). Measuring the environmental sustainability of a major sporting event: a case study of the FA Cup Final, Tourism Economics, 14 (4), 751-768.

- Costanza, R. (2000). The dynamics of the ecological footprint concept, Forum: the ecological footprint, Ecological Economics 32, 341-345.

- Dietz, T., Rosa, E.A., \& York, R. (2007). Driving the Human Ecological Footprint, Frontiers in Ecology and the Environment, 5(1), 8-13.

- Dodds, R., Graci, S. \& Holmes, M. (2010). Does the Tourist Care? Journal of Sustainable Tourism, 19 (2),207-222.

- Dolnicar, S, Laesser, C., \& Matus, K. (2010). Short-Haul City Travel is Truly Environmentally Sustainable. Journal of Sustainable Tourism, 16 (2), 197-210.

- Dwyer, L., Forsyth, P., Spurr, R. \& Hoque, S. (2010). Estimating the Carbon Footprint of Australian Tourism. Journal of Sustainable Tourism, 18(3), 355-376.

- Gössling, S. \& Hall, C.M. (2005). An Introduction to Tourism and Global Environmental Change. In: Gössling, S. \& Hall, C.M. (eds), Tourism and Global Environmental Change: Ecological, Social, Economic and Political Interrelationships. Routledge, London.

- Gössling, S., Hansson, C.B., Hörstmeier, O. \& Saggel, S. (2002). Ecological footprint analysis as a tool to assess tourism sustainability, Ecological Economics, 43, $199-211$.

- Hudson, S. \& Ritchie, J.R.B. (2001). Cross-Cultural Tourist Behavior: An Analysis of Tourist Attitudes towards the Environment, Journal of Travel and Marketing, 10, 2-22.

- Hunter, C. (2002). Sustainable tourism and the touristic ecological footprint, Environment, Development and Sustainability 4: 7-20. 


\section{Tourism Ecological Footprint: Energy Consumption of Domestic and International Tourists in Egypt}

- Jackson, M., White, G., \& Schmierer, C. (1996). Tourism Experiences Within an Attribution Framework. Annals of Tourism Research, 23, 798 - 810.

- Jennings, G. (2001). Tourism Research. Australia: Wiley.

- Kelly, J. \& Williams, P.W., (2007). Modelling tourism destination energy consumption and greenhouse gas emissions: Whistler, British Columbia, Canada. Journal of Sustainable Tourism 15 (1), 67-90.

- Kontogeorgopoulos, N. (2003). Keeping Up With the Joneses: Tourists, Travellers, and the Quest for Cultural Authenticity in Southern Thailand. Tourist Studies, 3, 171-203.

- Kuo, N.W. \& Chen, P.H. (2009). Quantifying Energy Use, Carbon Dioxide Emission, and Other Environmental Loads from Island Tourism Based on a Life Cycle Assessment Approach, Journal of Cleaner Production, 17, 1324-1330.

- Ministry of Tourism (2014). Tourism in Figures, Ministry of Tourism, Tourism General Department For Information and Statistics, 63-64.

- Patterson, T.M., Niccolucci, V. \& Bastianoni, S. (2007). Beyond "more is better: Ecological Footprint accounting for tourism and consumption in Val di Merse, Italy, Ecological Economics, 62, pp. 747-756.

- Patterson, T.M., Niccolucci, V., \& Marchettini, N. (2008). Adaptive Environmental Management of Tourism in the Province of Siena, Italy Using the Ecological Footprint. Journal of Environmental Management, 86, 407-418.

- Paul, A., Wiedmann, T., Barrett, J., Minx, J., Scott, K., Dawkins, E., Owen, A., Briggs, J., and Gray, I. (2010). Introducing the Resources and Energy Analysis Programme (REAP).

- SEI, Stockholm, Sweden. Peters, P., \& Schouten, F. (2006). Reducing the ecological footprint of inbound and transport to Amsterdam. Journal of Sustainable Tourism, 14(2), 157-171.

- Peng, L. \& Guihua, Y. (2007). Ecological Footprint study on Tourism Itinerary Products in Hangri-La, Yunnan Province, China, Acta Ecologica Sinica, 27 (7), 2954-2963.

- Pongsakornrungsilp, P. (2011). Energy consumption and the ecological footprint of tourism in an island destination: the case of Kom Samui, Thailand, $\mathrm{PhD}$ thesis, University of Exeter.

- Rahman, I., Reynolds, D., \& Svaren, S. (2012). How "green" are North American hotels? An exploration of low-cost adoption practices. International Journal of Hospitality Management, 31, 720-727.

- Ross, A. (2006). Ecological Footprint: the Journey So Far, Lesson Sharing and Case Studies of Local Authorities in the UK. World Wide Fund for Nature UK (WWF- UK), Surrey.

- Ruane, J. M. (2005). Essentials of Research Methods: A Guide to Social Science Research. Malden, MA: Blackwell Publishing.

- Sisman, D. (2007). Tourism Destinations Carbon Footprints, Available at: http://www.thetravelfoundation.org.uk/images/media/7._Carbon_footprint_calculation_gui de.pdf. Retrieved on 12-3-1014.

- Sonak. S. (2004). Ecological Footprint of Production: A Tool to Assess Environmental Impacts of Tourism Activity. Journal of Tourism Studies, 15 (2), 2-12.

- Stoeglehner, G. \& Narodoslawsky, M. (2009). How Sustainable Are Biofuels? Answers and Further Questions Arising From an Ecological Footprint Perspective. Bioresource Technology, 100(16), 3825-3830.

- Swarbrooke, J. \& Horner, S. (2004). Consumer Behaviour in Tourism. Butterwortheinemann, Burlington.

- Taylor, S., Peacock, A., Banfill, P., \& Shao, L. (2010). Reduction of greenhouse gas emissions from UK hotels in 2030. Building and Environment, 45, 1389-1400.

- Teng, C. C., Horng, J. S., Hu, M. L., Chien, L. H., \& Shen, Y. C. (2012). Developing energy conservation and carbon reduction indicators for the hotel industry in Taiwan. International Journal of Hospitality Management, 31, 199-208. 
- Tsai K.T., Lin, T.P., Hwang, R.L., \& Huang, Y.J. (2014). Carbon dioxide emissions generated by energy consumption of hotels and homestay facilities in Taiwan, Tourism Management 42, 13-21.

- Van den Bergh, J. \& Verbruggen, H. (1999). Spatial sustainability, trade and indicators: an evaluation of the Ecological Footprint, Ecological Economics, 29, pp. 61-72.

- Van Middelkoop, M., Borgers, A., \& Timmermans, H. (2003) Inducing Heuristic Principles of Tourist Choice of Travel Mode: A Rule-Based Approach. Journal of Travel Research, 42, $75-83$.

- Venetoulis, J. \& Talberth, J. (2008). Refining the ecological footprint, Environ Dev Sustain, 10, 441-469.

- Wackernagel, M., Monfreda, C., Moran, D., Wermer, P., Goldfinger, S., \& Deumling, D. (2005). National footprint and biocapacity accounts 2005: The underlying calculation method. Oakland, California: Global Footprint Network.

- Wackernagel, M. \& Rees, W.E. (1996). Our Ecological Footprints: Reducing Human Impact on the Earth, Gabriola Island, BC, New Society Publishers.

- Wackernagel, M. \& Yount, J.D. (2000). Footprints for sustainability: the next steps. Environment, Development and Sustainability 2: 21-42.

- Wang, D. (2011). Tourist Behavior and Repeat Visitation to Hong Kong. Tourism Geographies, 6 (1), $99-118$.

- Wang, J. C. (2012). A study on the energy performance of hotel buildings in Taiwan. Energy and Buildings, 49, 268-275.

- Wang, J. C., \& Huang, K. T. (2013). Energy consumption characteristics of hotel's marketing preference for guests from regions perspective. Energy, 52, 173-184.

- Woodside, A. \& King, R., (2001). An Updated Model of Travel and Tourism PurchaseConsumption Systems. Journal of Travel and Tourism Marketing, 10(1), 3-27.

- World Tourism Organization, United Nations Environment Programme and World Meteorological Organization (2008) Climate Change and Tourism - Responding to Global Challenges. Available at http:// sdt.unwto.org/sites/all/files/docpdf/climate2008.pdf.

Retrieved on 15-04-2014.

- World Wildlife Fund (WWF) (2012). Africa Ecological foot print report: green infrastructure for Africa's ecological security, available at http://www.afdb.org/fileadmin/uploads/afdb/Documents/Publications/Africa\%20Ecologica $1 \% 20$ Footprint $\% 20$ Report $\%$. Retrieved on 13-5-2014.

- Yin, R. K. (2003). Case Study Research: Design and Method, Ed.3. California: Sage Publishing, Inc. 


\section{Tourism Ecological Footprint: Energy Consumption of Domestic and International Tourists in Egypt}

البصمة البيئية للسياحة: استهلاك السائحون الاذخليون والدوليون للطاقة في مصر

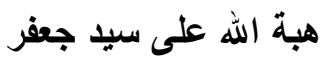

كلية السياحة والفنادق - جامعة مدينة السادات

تطبق العديد من الدول البصمة البيئية للسياحة للتعرف على الأثر البيئي لسلوك وأنثطة السياح من

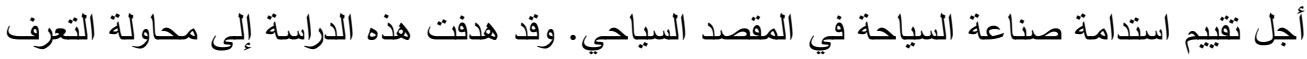

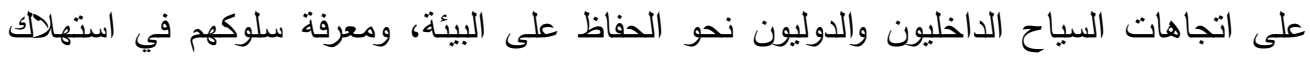
الطاقة. وقد حاولت هذه الدراسة التعرف على العوامل التي قد تؤثر في اتجاهات وسلوك السياح نحو

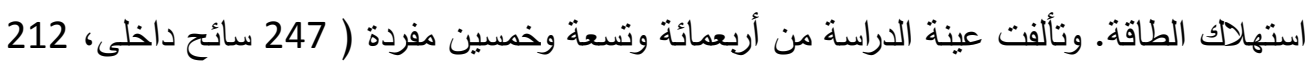

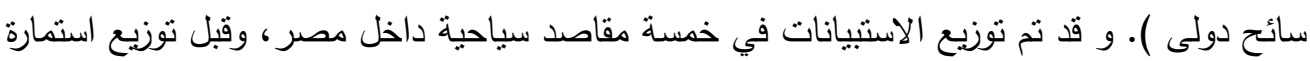
الاستقصاء النهائية نم عمل دراسة تجريبية على عينة مكونة من ستين سائح. وقد أثنتت النتائج وجود فروق ذات دلالة إحصائية بين مجموعتي الدراسة بشأن اتجاهاتهم وسلوكهم نحو استهلاك الطاقة

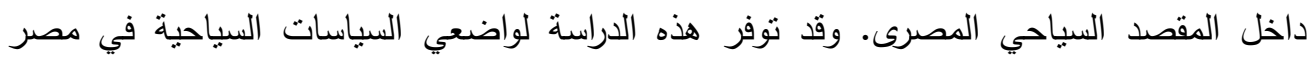

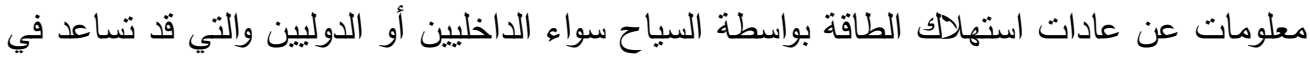

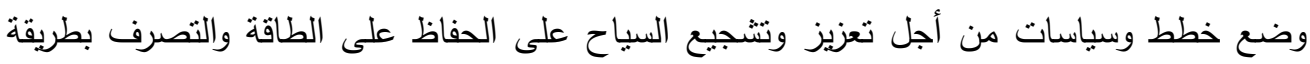

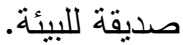

